\title{
Políticas linguísticas na área indígena dos Karipuna do Amapá: o caso do kheuól
}

\author{
Romário Duarte Sanches ${ }^{1}$ \\ Kelly Cristina Nascimento Day ${ }^{2}$ \\ Universidade do Estado do Amapá, Macapá, AP, Brasil
}

Resumo: Este artigo apresenta as políticas linguísticas in vitro e in vivo nas aldeias indígenas do povo Karipuna do Amapá, localizadas na região fronteiriça entre Brasil e Guiana Francesa. Como referencial teórico, adotam-se conceitos e questões amplamente discutidos por Haugen (1972), Rousseau (2005), Calvet (1996), Shohamy (2006), Spolsky (2004), Robillard (1997), entre outros, relacionados ao campo de políticas linguísticas, com destaque para aquelas destinadas às populações indígenas brasileiras. Os resultados apresentados provêm da análise de dados quanti-qualitativos coletados por meio de questionário sociolinguístico aplicado a 36 indígenas bilíngues (falantes de português e kheuól) da etnia Karipuna do Amapá. A partir desses dados, foi possível constatar quais políticas são reivindicadas ao poder público e quais estão sendo implementadas pela comunidade em prol da manutenção do kheuól nas comunidades Karipuna.

Palavras-chave: Política linguística; Kínguas minoritárias; Língua kheuól.

Title: Linguistic policies in the indigenous area of the Karipuna do Amapá: the case of Kheuól

Abstract: This article presents in vitro and in vivo linguistic policies in the indigenous villages of the Karipuna do Amapá people, located in the border region between Brazil and French Guiana. As a theoretical framework, concepts and issues widely discussed by Haugen (1972), Rousseau (2005), Calvet (1996), Shohamy (2006), Spolsky (2004), Robillard (1997), among others, related to the field of linguistic policies, with emphasis on those selected for Brazilian indigenous. The presented results provide analysis of quantitative and qualitative of data collected through a sociolinguistic questionnaire applied to 36 bilingual indigenous (Portuguese and Kheuól speakers) of the Karipuna do Amapá ethnic group. From these data it was possible to verify which policies are claimed by the public authorities and which are being implemented by the community in favor of maintaining the kheuól in the Karipuna communities.

Keywords: Linguistic policy; Minority languages; Kheuól language.

1 Doutorado em Letras (UFPA), Professor da Universidade do Estado do Amapá (UEAP). Orcid: https://orcid.org/0000-0002-0571-303X. E-mail: romario.sanches@ueap.edu.br.

${ }^{2}$ Doutorado em Estudos da Linguagem (UFF), Professor adjunto da Universidade do Estado do Amapá (UEAP). Orcid: https://orcid.org/0000-0002-2077-7832. E-mail: kelly.day@ueap.edu.br. 


\section{Introdução}

Historicamente, as línguas têm sido usadas como instrumento de dominação sociopolítica dos povos. Na constituição da sociedade brasileira, essa realidade não foi diferente. As populações indígenas brasileiras foram alvo de inúmeros atos de políticas linguísticas, oficiais ou não, desde o período colonial e continuam a sê-lo. Das políticas de catequização, integração, até a formatação da educação bilíngue na constituição de 1988, as iniciativas políticas tiveram como objeto de alcance as línguas utilizadas pelas comunidades indígenas, sua transmissão, normatização ou mesmo o apagamento delas.

Nos últimos 30 anos, especialmente após a promulgação da Constituição Federal de 1988 e posteriormente à Lei de Diretrizes e Bases da Educação de 1996 - LDB (9394/96), as línguas indígenas brasileiras, em que pese à alta vulnerabilidade em que se encontra a maioria delas, têm registrado movimentos políticos-linguísticos diversos, conduzidos em muitos casos por iniciativa das próprias comunidades autóctones, na busca da reafirmação de suas identidades culturais através da revitalização de suas línguas. Nesse âmbito, incluise, a título de exemplo, a cooficialização ${ }^{3}$ de diversas línguas indígenas, particularmente na região amazônica. Tais políticas, denominadas linguísticas são, antes de tudo, atos sociais que visam regular o uso das línguas em uma comunidade, região ou país de modo incitativo ou por imposição.

Como parte da história social de um povo (HAMEL, 1996), as políticas linguísticas podem tanto originar-se de iniciativas autorregulatórias como provir da intervenção do Estado. Nesse sentido, "toda forma de decisão tomada por um Estado, por um governo, por um agente social reconhecido ou revestido de autoridade, destinada a orientar a utilização de uma ou de várias línguas sobre um dado território (real ou virtual) ou regulamentar o seu uso" (ROUSSEAU, 2005, p. 58) é um ato de política linguística.

Nesse âmbito, este artigo discute as políticas linguísticas em voga para as minorias indígenas brasileiras e aborda, em particular, as políticas in vitro e in vivo (CALVET, 2007) nas aldeias indígenas dos Karipuna do Amapá na região fronteiriça entre Brasil e Guiana Francesa. O objetivo principal deste estudo é mostrar as iniciativas utilizadas pelos indígenas, nas diferentes comunidades, para manter o uso do kheuól, como língua nativa dessas comunidades, partindo do pressuposto que tais políticas dependem do grau de vitalidade dessa língua e das atitudes e representações dos falantes para com ela (FISHMAN, 1996). Assim, apresentamos primeiramente uma breve revisão conceitual sobre Política e Planificação Linguística com foco em noções de políticas in vivo e in vitro (CALVET, 2007), bem como de planificação de corpus e de status linguístico (COOPER, 1989) em direta correlação com as políticas direcionadas às minorias linguísticas indígenas brasileiras. Em seguida, apresentamos os povos indígenas da região do Oiapoque, no Amapá, descrevemos

\footnotetext{
${ }^{3}$ Dados do IPOL apontam que até 2014, (7) sete línguas indígenas foram declaradas línguas cooficiais em 5 (cinco) municípios brasileiros: Tukano, Neengatu e Baniwa em São Gabriel da Cachoeira no Amazonas; Guarani em Tacuru (MS), Akwê Xerente em Tocantínia (TO), Mucuxi em Bonfim (RR) e Wapichana nos municípios de Bonfim e Cantá (RR). Dados disponíveis em: http://ipol.org.br/lista-de-linguas-cooficiais-em-municipiosbrasileiros/. Acesso em 16 abr. 2020.
} 
o método de pesquisa aplicado a este trabalho, considerando os procedimentos de análise, e, por fim, são apresentados os resultados quanti-qualitativos e a discussão empreendida em torno das políticas in vivo e in vitro observadas nas e pelas comunidades Karipuna para a preservação do kheuól.

\section{Políticas linguísticas para os povos indígenas do Brasil}

Atualmente, com base nas diretrizes do Inventário nacional da Diversidade Linguística (INLD), Brasil (2014), o Brasil possui como línguas faladas, além do português e suas variedades, mais de 200 línguas, somando-se as línguas indígenas, de imigração, crioulas e de sinais. Por outro lado, o Censo Demográfico de 2010, realizado pelo Instituto Brasileiro de Geografia e Estatística (IBGE), registrara a existência de 274 línguas e cerca de 300 etnias. Tais dados, se por um lado exibem a dimensão da diversidade linguística brasileira, por outro permitem inferir a existência de políticas linguísticas diversas no processo de expansão da língua portuguesa e de extermínio de inúmeras línguas indígenas, o que supõe inevitavelmente conflito linguístico entre povos de maior e menor status social, político e econômico dentro do território nacional.

Tradicionalmente, intervenções linguísticas nas organizações sociais, antigas ou contemporâneas, estiveram ao lado de práticas de dominação, subjugo e mesmo de sobrevivência e representam, portanto, estratégias políticas nada recentes. A denominação Política e Planificação Linguística, por sua vez, enquanto campo de estudo e pesquisa, é bastante recente e correlaciona-se com o reconhecimento de sua especificidade e sua inclusão no campo político e de pesquisa linguística.

Política e planificação linguística ${ }^{4}$ constituem um binômio largamente discutido na literatura $^{5}$, embora não seja consenso, dadas as variadas nuances incorporadas aos conceitos. Concordando com Laporte (1994), consideramos que uma política linguística representa um quadro jurídico e/ou ideológico, enquanto a planificação reúne diferentes ações que tem por objetivo conferir um status particular a uma ou várias línguas (LAPORTE, 1994, p. 97, grifo nosso). A aliança destes termos representa a união de ideologias linguísticas e intervenções práticas no dia a dia dos grupos sociais (DAY, 2016).

Diversos estados e governos optaram por uma política linguística estabelecida por meio da legislação. Estima-se, atualmente, que a maioria dos países membros das Nações Unidas adote uma política linguística regida por instrumentos legislativos. Considerada um dos principais instrumentos do planejamento linguístico, a legislação linguística tem como objetivos fixar "as regras que determinam a escolha das línguas em certos domínios da vida social" e "determinar as circunstâncias" (CALVET, 1996), que podem assegurar ou delimitar o

\footnotetext{
${ }^{4}$ A primeira noção conceitual de planejamento linguístico (language planning) surge em 1959 em um artigo de Haugen relativo aos problemas linguísticos da Noruega.

${ }^{5}$ Cooper (1997) cita doze autores que tentam definir o termo language planning: Prator (1969), Haugen (1969), Thorburn (1971), Rubin e Jernudd (1971), Jernudd e Das Gupta (1971), Gorman (1973), Das Gupta (1973), Fishman (1974), Tauli (1974), Karan (1974), Weinsten (1980), Neustupny (1983), cobrindo uma enorme gama de domínios e atividades sociais.
} 
uso das línguas, principalmente nas situações que envolvem minorias linguísticas. Os textos oficiais aparecem, tanto nas constituições, como é o caso no Brasil, na França ou na Espanha, quanto através de leis específicas que distinguem, entre outras coisas, os domínios de uso, como ocorre no Quebec, na Catalunha etc.; ou ainda em leis setoriais quando direcionadas, entre outros, à determinação de línguas de ensino, línguas estrangeiras, línguas de trabalho, da administração pública etc.

Outro par conceitual introduzido por Kloss (1969), no âmbito da política linguística e seu campo de atuação, diz respeito à planificação do corpus (Sprachplanung) e a planificação do status (Statusplanung) de uma língua. Planificar o corpus envolve atos que visam definir o lugar que uma língua ocupa ou deverá ocupar em uma rede de relações sociais, ou seja, nos casos de línguas ágrafas, situação em que se encontram diversas línguas indígenas no Brasil, significa a adoção de um sistema de escrita, codificação, padronização fonética, desenvolvimento de gramáticas e dicionários, entre outros. A planificação do status (cf. SAVEDRA; LAGARES, 2012) abrange ações externas às línguas e comumente envolve os usos e papéis sociais que elas ocupam em contextos multilíngues. Para Robillard (1997, p. 269), essa planificação refere-se à posição de uma língua na hierarquia sociolinguística de uma comunidade linguística, estando essa posição ligada às funções ocupadas pela língua e ao valor social relativo conferido às suas funções.

Posteriormente, Cooper (1989) introduz um terceiro elemento na proposta de Kloss (1969), a planificação da aquisição. No âmbito dela, estão circunscritos a expansão do número de falantes, os processos de ensino, a definição de o que ensinar e o para quem. Este conceito se mostra particularmente relevante no caso da manutenção de línguas indígenas como o kheuól por representar a adoção e a gestão consciente de práticas linguísticas especialmente junto às novas gerações.

Nesse sentido, colocando em destaque a gestão das políticas linguísticas, Calvet (1996, p. 68-70) diferencia aquelas que decorrem das práticas sociais, ou seja, das soluções encontradas pelas pessoas no seu dia a dia para uma dada situação linguística, denominadas políticas in vivo, daquelas cujas ações procedem do poder público, fruto da intervenção do Estado, por meio de leis e decretos, as políticas in vitro.

Nessa mesma linha, acrescenta-se que a compreensão das políticas linguísticas contemporâneas passa muito mais pela análise das práticas linguísticas e representações que pelo ordenamento jurídico (SPOLSKY, 2004). Assim, Shohamy (2006) aponta a existência tanto de políticas explícitas e formalizadas quanto de políticas implícitas e informais que podem estar em ação numa mesma comunidade, muitas vezes agindo em sentidos opostos. A autora faz distinção ainda entre as políticas declaradas, com agenda e as não declaradas ou ocultas, cuja noção conceitual determinante é a de mecanismos, isto é, instrumentos através dos quais as políticas são reproduzidas nas sociedades, incorporando as agendas ocultas e atuando de forma implícita ou explícita. São os mecanismos que efetivamente sustentam a ou as verdadeiras políticas linguísticas de uma sociedade.

Seguramente, o assentamento jurídico, tal qual o diretório dos índios de 1757, foi um dos instrumentos explícitos utilizados no apagamento de inúmeras línguas indígenas no 
Brasil, mas não foi o único. Muitas ações não declaradas do poder público, como a política de extermínio e escravização dos indígenas, de incentivo ao casamento com brancos, a ausência de ações linguísticas afirmativas para essas comunidades, entre outros, colaboraram para o cenário atual de desaparecimento linguístico. O estudo das cartas constitucionais feitas por Rodrigues (1988) revela a omissão do estado brasileiro na preservação do patrimônio linguístico nacional. Assim, vale reiterar que as políticas governamentais declaradas ou ocultas têm grande impacto na diversidade linguística, podendo tanto colaborar para a manutenção quanto para o desaparecimento das línguas em uma sociedade.

Para Shohamy (2006), a efetividade dos mecanismos implícitos se dá em função de seu caráter aparentemente neutro e não impositivo, pois:

[...] isso também significa que as pessoas se sujeitam, sem questionar, às demandas impostas pelos mecanismos visto que elas não têm consciência das influências negativas associadas a eles, em termos de direitos linguísticos e democráticos [...] (SHOHAMY, 2006, p. 55).

Corbeil (2002), por sua vez, aponta para a necessidade de identificar os domínios de uso e, portanto, de concorrência de uma língua quando se avalia a eficácia ou a viabilidade de uma política linguística. Para o autor, são cinco os principais domínios de uso:

a) a família e o grupo social - é daí que decorre a transmissão geracional;

b) a escola e o processo de escolarização - onde a concorrência entre as línguas se mostra mais efetiva;

c) a gestão do estado - a comunicação do estado com o cidadão é feita por meio de uma ou mais línguas;

d) a atividade econômica - o domínio das atividades econômicas perpassa pelo uso da língua dominante no mercado; e

e) as atividades científicas e tecnológicas - viabilizam o acesso à tecnologia e à informação e promovem difusão de conhecimento, inclusive das línguas.

Vale lembrar que os domínios de uso, bem como o número de falantes têm direta correlação com a vitalidade de uma língua. A ausência de transmissão entre os mais velhos e as novas gerações, aliadas às pressões econômicas e sociais que as línguas sofrem tanto em seu ambiente de uso quanto no seu entorno são determinantes no seu desaparecimento (FISHMAN, 1991). Para além dos aspectos supracitados, é válido salientar que toda planificação linguística deve estar fundamentada em uma perspectiva da situação linguística desejada, das relações que se pretende estabelecer entre as comunidades linguísticas em presença, dos usos da língua que se pretende implementar ou reforçar e das mudanças que se pretende estabelecer (DAY, 2016). Respostas a estas questões é que permitem definir qualitativamente os objetivos de uma planificação linguística.

Tendo como pano de fundo os pressupostos supracitados, observa-se que no Brasil, as políticas que afetaram diretamente o uso, a presença e ou a manutenção das línguas 
indígenas compõem um vasto histórico de intervenções linguísticas em todo o território nacional, revestidas muitas vezes de um caráter ideológico nacionalista, conciliatório e integrador, atuando, via de regra, em favor da língua portuguesa e acentuando a assimetria linguística desta com as demais línguas brasileiras. Dentre tais políticas, a mais marcante é, inconteste, o Diretório dos índios de 1757, instituindo o uso da língua portuguesa e proibindo o ensino e o uso das línguas indígenas e da Língua Geral no Brasil (CRUZ, 2006, p. 43), fato que corrobora a noção de que a perda linguística ou o silenciamento das línguas indígenas se mostram vir acompanhadas de investimento sucessivo e contínuo na desvalorização e na opressão dos povos autóctones brasileiros.

Por cerca de 200 anos, as línguas indígenas foram mantidas à margem da política linguística oficial brasileira, sendo, quando muito, permitido o seu uso local e interpessoal. Mantidas distante das escolas e dos serviços públicos de atendimento ao cidadão, essas línguas foram enfraquecidas no seio das comunidades indígenas e cederam espaço para a língua majoritária do país. Com efeito, o Estatuto do Índio de 1973 (Lei 6.001/73) é o primeiro ato político-linguístico que confere autorização para que os indígenas sejam alfabetizados "na língua do grupo", porém o caráter integracionista que sustenta implícita e explicitamente o documento o fez alvo de inúmeras críticas.

É a Constituição Federal de 1988 que confere direitos linguísticos efetivos através de uma política de reconhecimento étnico, sociocultural e linguístico aos grupos indígenas brasileiros. 0 artigo 210 assegura, por exemplo, às comunidades indígenas, o uso de suas línguas maternas e processos próprios de aprendizagem, sendo dever de o Estado proteger as culturas indígenas.

Ainda no mesmo documento, o Art. 231 determina:

São reconhecidos aos índios sua organização social, costumes, línguas, crenças e tradições, e os direitos originários sobre as terras que tradicionalmente ocupam, competindo à União demarcá-las, proteger e fazer respeitar todos os seus bens (BRASIL, 1988, p. 133).

A Lei de Diretrizes e Bases da Educação (LDB) de 1996, por sua vez, respaldada pela Constituição Federal de 1988, garante a oferta de educação bilíngue e intercultural aos povos indígenas, possibilitando a existência de escolas com características específicas, que "buscasse a valorização de suas línguas e ciências" (Art. 78, p. 31) e que ao mesmo tempo fornecesse instrumentos que permitissem o contato com outras sociedades.

Por um lado, o art. 26 estabelece:

Os currículos do ensino fundamental e médio devem ter uma base nacional comum, a ser complementada, em cada sistema de ensino e estabelecimento escolar, por uma parte diversificada, exigida pelas características regionais e locais da sociedade, da cultura, da economia e da clientela (BRASIL, 1996, p. 16).

E, em complemento, o § 3 o do Art.32 da LDB 9.394/96 assegura que o ensino fundamental regular será ministrado em língua portuguesa, assegurada às comunidades indígenas a utilização de suas línguas maternas e processos próprios de aprendizagem. 
O Referencial Curricular Nacional para a Escola Indígena (RECNEI) explicita que a língua indígena, além de ser a língua de instrução oral, deve ser também a língua de instrução escrita predominante em situações relacionadas aos conhecimentos étnicos e científicos tradicionais, conforme os termos abaixo:

A língua indígena será, (...), a língua através da qual os professores e os alunos discutem matemática, geografia, etc... Esse tipo de procedimento permite que os alunos que têm pouco domínio do português possam aprender melhor e mais rapidamente os novos conhecimentos de fora, necessários devido ao contato com a sociedade envolvente (BRASIL, 1998, p. 119).

Contudo, o ordenamento jurídico em si mesmo não assegura que tais políticas não sejam apenas declarações de intenções (SHOHAMY, 2006), o direito de uso das línguas indígenas, na prática se mostra restrito ao ambiente indígena, posto que para qualquer outro cenário além dos limites geográficos das aldeias, o império da língua portuguesa se mostra uma barreira consistente contra os avanços de qualquer outra língua minoritária. 0 aparato legal, ainda que válido e importante, permanece, em muitos casos, apenas como elemento figurativo e simbólico dado que os dispositivos e meios para a sua efetivação não foram previstos e/ou colocados em prática. Eis, portanto, a razão pela qual diferentes comunidades indígenas se organizam tanto para reivindicar ações que, em tese, estão garantidas pela constituição, quanto para salvaguardar o uso de suas línguas no ambiente social em que vivem.

\section{Os povos indígenas da região do Oiapoque}

A cidade de Oiapoque está localizada no norte do estado do Amapá e faz fronteira com Saint Georges, pequena cidade francesa, pertencente à Guiana Francesa, localizada na margem esquerda do Rio Oiapoque, zona limítrofe que divide o Brasil da Guiana Francesa (IBGE, 2010).

O termo 'região do Oiapoque ${ }^{6}$, que será constantemente usado no decorrer do texto, não se restringe apenas ao município amapaense, mas a todo o seu entorno que envolve as populações indígenas, quilombolas, caboclas, migrantes e imigrantes.

A história da cidade de Oiapoque tem suas imprecisões, assim como a história dos povos indígenas dessa fronteira. Nesta seção, buscamos reunir informações pontuais, com base no estudo feito por Tassinari (2003), para caracterizar historicamente os povos dessa região, sobretudo a etnia indígena Karipuna do Amapá.

Tassinari (2003) assegura que a caracterização dos povos indígenas da região do Oiapoque está relacionada com o processo de ocupação, de exploração e de povoamento da Amazônia brasileira. Este cenário é descrito em fontes historiográficas que versam sobre a história da região do baixo Oiapoque, mostrando que desde o século XVI diversos grupos indígenas de diferentes famílias linguísticas (Aruák, Karíb e Tupi-Guarani) estiveram em

\footnotetext{
${ }^{6}$ Termo usado por Sanches (2020).
} 
contato com outros grupos de nacionalidades distintas (franceses, portugueses, holandeses, ingleses), além de negros refugiados ou alforriados da época. A maioria dos estrangeiros fazia parte das expedições missionárias, comerciais, armadas ou científicas, e, de alguma forma, estabeleceu diferentes contatos.

No início do século XVII, tem-se, nos relatos de Mocquet (1617) e D’Avity (1643), menção ao país dos Caripous, vizinho dos Caribes, sendo os dois habitados por povos "inimigos". Ainda nesse século, foram empreendidas as primeiras tentativas de estabelecimento de colônias europeias no Oiapoque (de origem inglesa, francesa e holandesa). Boa parte dessas expedições durou pouco, não cumprindo com o objetivo dos povos de se fixarem na região. Já na segunda metade do século XVII, os franceses fixaram-se definitivamente em Caiena, entretanto, o contingente indígena do litoral foi reduzido a 3.500 pessoas entre o Rio Cachipour (atualmente denominado de Rio Cassiporé) e Rio Maroni, entre os quais se verificou a existência de aproximadamente quarenta indígenas Yaos (TASSINARI, 2003).

Outro registro importante, datado do final do século XVII, corresponde à migração do grupo Aroua, que se refugiou na Guiana Francesa em decorrência das políticas de conquista portuguesa.

No século XVIII, os grupos indígenas da região do Oiapoque sofreram pressões tanto do lado dos colonizadores portugueses como de grupos indígenas e dos negros refugiados no Suriname (Djuka, Samaraka e Boni). De acordo com Hurault (1972), as missões jesuíticas (1758-1763) percorreram o interior da região do Oiapoque, mas não obtiveram êxito. No final deste século, registrou-se ali o ataque abrupto da coroa portuguesa, que se instalou com o objetivo de ocupar e despovoar o território até então contestado pela França. Tratase do período no qual as "expedições portuguesas queimam aldeias, destroem estabelecimentos e casas de colonos franceses, invadem os territórios das missões, aprisionam a população indígena, e deportam para o Amazonas" (TASSINARI, 2003, p. 93).

Nimuendaju (1926) acrescenta que no século XVIII, a maioria dos Aroua refugiou-se no alto Uaçá e que entre esses indígenas também constava um número significativo de grupos que falavam a Língua Geral Tupi, denominados na Guiana como língua Karipuna.

Em relação ao século XIX, Hurault (1972) ressalta que os dados sobre as populações indígenas do Oiapoque estão restritos aos relatos feitos pelos viajantes. As expedições foram realizadas com objetivos diversos, nelas, os viajantes estabeleceram contato com os Wajãpi, Wayana e Émerillon. Durante esse período, estabeleceram-se no Oiapoque vários grupos indígenas vindos do território contestado e de outros lugares do Brasil, alguns, dizimados pelas epidemias e pela exploração da mão de obra.

Com a chegada de diferentes povos na região do Oiapoque, uma nova configuração étnica foi se formando, como apontam Crevaux (1883) e Coudreau (1893) (apud TASSINARI, 2003, p. 95), ao descreverem a população indígena mestiça e "creolizada" existente naquela área.

Durante o século XX, atesta-se a presença do Governo brasileiro e de órgãos missionários no Oiapoque. Este período foi marcado pela decisão do laudo suíço, que 
determinou que a região contestada pela França (a região do Oiapoque) passasse a pertencer ao Brasil. Esse fato foi determinante para dar início a uma política de "abrasileiramento" da região.

No que diz respeito à urgência de se "abrasileirar" a população da região contestada, sobretudo, o povo indígena considerado francês, foram executados projetos de ocupação do território, a exemplo da criação da Comissão Colonizadora do Oiapoque. Na vila Martinica (no Oiapoque), a comissão fundou, no ano de 1922, a Colônia Agrícola de Clevelândia, recebendo pessoas provenientes principalmente do Nordeste brasileiro.

Em 1927, o Governo brasileiro volta atenção para as populações indígenas da região, por iniciativa da Comissão de Inspeção de Fronteiras do Ministério da Guerra (CIFMG), chefiada pelo general Rondon. Esta comissão, em seus relatórios, já assinalava a implantação de postos indígenas e escolas, como forma de inserir a população indígena na sociedade.

A criação de escolas em área indígena ocorreu durante o ano de 1934 de forma precária, com estruturas inadequadas oferecidas aos profissionais que atuavam nas aldeias. Segundo Tassinari (2003), a escola teve papel decisivo na formação da atual identidade dos diferentes grupos indígenas, bem como, na propagação do português e na configuração de novas aldeias. Juntamente com a implantação das escolas, houve a imposição do sentimento nacionalista, já que os alunos indígenas foram instruídos a hastear a bandeira brasileira, comemorar o feriado de Sete de Setembro, cantar o hino nacional e estimulados à prática do futebol.

Na metade do século XX, sucederam outros fatores que contribuíram para a história da região, a exemplo da migração de famílias Galibi do Mana, na Guiana Francesa, e da instalação dos missionários batistas do Summer Institute of Linguistic (SIL), na presença do casal Harold e Diana Green. Durante a década de 1970, observa-se a presença da Fundação Nacional do Índio (FUNAI) e do Conselho Indigenista Missionário (CIMI).

A FUNAI criou diversos postos indígenas e incentivou a ocupação da área indígena na BR-156 (Rodovia que liga a capital Macapá com Oiapoque), proporcionando a criação de novas aldeias. A presença do CIMI, representada pelo padre Nello Ruffaldi e pela irmã Rebecca Spires, auxiliou os indígenas a desenvolver uma identidade conjunta, compartilhada por quatro povos indígenas do Oiapoque, que pôs em prática projetos voltados à autonomia dos grupos, no intuito de valorizar a cultura local e de incentivar o uso das línguas indígenas para execução de atividades de cunho educacional, político, econômico e religioso.

A partir de levantamento histórico sobre os povos da região do Oiapoque, é possível notar a complexidade cultural e linguística existente ali. Atualmente, há quatro etnias indígenas fixadas em aldeias localizadas às margens dos rios Uaçá, Urukawá, Curipi e Oiapoque (SANCHES, 2020), conforme mostra a Figura 1. 
Figura 1 - Terras Indígenas Uaçá, Galibi e Juminã

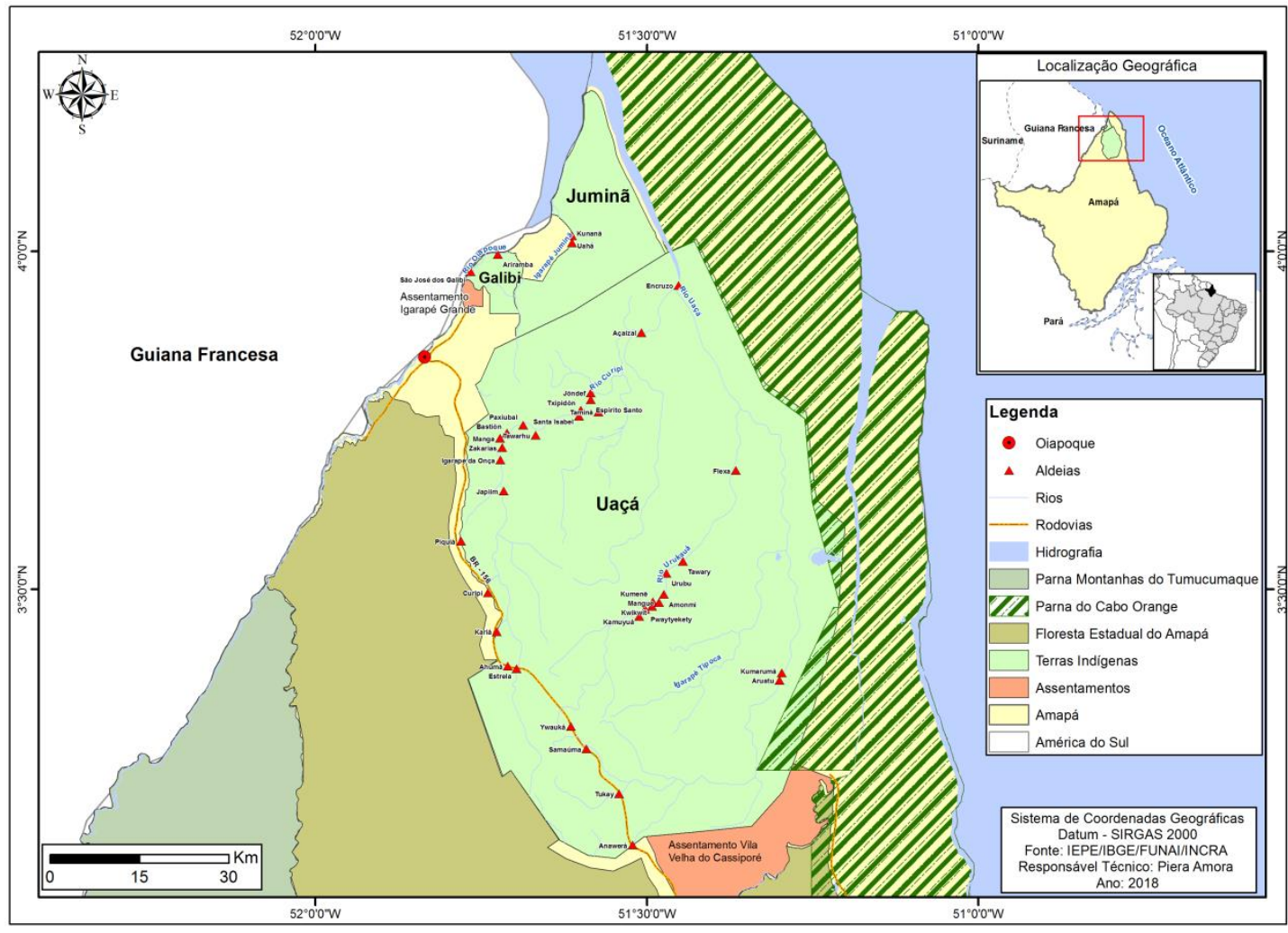

Fonte: Sanches (2020).

Na Figura 1, ilustra-se a diversidade étnica da região por Terra Indígena (TI). A TI Galibi conta com uma superfície de 6.889 ha, sendo a primeira homologada na região do Oiapoque - AP, em 22 de novembro de 1982. A TI Uaçá apresenta uma superfície de 470.164 ha, sendo homologada em 30 de outubro de 1991. E, por último, a TI Juminã, com uma superfície de 41.601 ha, homologada em 22 de maio de 1992.

A figura acima também mostra três Terras Indígenas: TI Uaçá, TI Galibi e TI Juminã. Nelas residem as etnias: Karipuna, Palikur, Galibi-Marworno e Galibi Kali'nã. De acordo com o banco de dados da FUNAI regional, a população indígena soma 7.163, distribuída em 50 aldeias.

Na Terra Indígena Uaçá concentra-se o maior número de famílias indígenas, distribuídas ao longo da BR-156, à margem dos rios Curipi, Urukawá e Uaçá. Na BR-156 estão localizadas as aldeias Yawauká, Kuahi, Estrela, Ahumã, Curipi, Piquiá, Kariá, Tukay, Samauma, Tuluhí e Anuerá. A população total na BR 156 está estimada em 687 indígenas.

Nas aldeias localizadas à margem do Rio Curipi, estão instaladas as de origem Karipuna: Manga, Espírito Santo, Santa Izabel, Açaizal, Taminã, Cutiti/Jõdef, Japiim, Txibidon, Paxiubal, Benoá, Zacarias, Bastion, Encruzo, Pakapuá e Igarapé da Onça, com uma população total estimada de 2.490 pessoas. Ainda na TI Uaçá estão as aldeias da etnia Palikur, localizadas ao longo do Rio Urukawá: Kumenê, Kamuyuwá, Flecha, Amomim, Pywatyket, Tawary, Kuwikuwit, Khobo, Mangue-i, Tipoca, Yanawá. Todas estas somam cerca 1.500 indígenas. Finalizando, na TI Uaçá, no leito do rio que dá o nome à área indígena (Rio Uaçá), 
concentram-se os indígenas da etnia Galibi-Marworno: Kumarumã, Aruatú, Paraikô, Paramwaká, Flamã, Karibuene, Kaxiuahi, Tucuiuí e Magí. Até o momento, a população soma 2.119 indígenas.

A TI Galibi, compreende duas aldeias: a aldeia Ariramba, pertencente à etnia Karipuna e a aldeia Galibi do Oiapoque, da etnia Galibi Kali'nã, localizadas no curso do Rio Oiapoque, com um total de 168 indígenas. Por último, tem-se a TI Juminã, com as aldeias Kunanã e Uahá, localizadas no Igarapé Juminã. A primeira pertence ao grupo Karipuna e, a segunda, ao grupo Galibi-Marworno. Somam um total de 179 indígenas ${ }^{7}$.

Atualmente, de acordo com Sanches (2020), a população Karipuna e Galibi Marworno fala kheuól e português, sendo esta primeira língua considerada uma variedade crioula de base francesa falada na Guiana Francesa ${ }^{8}$. Já os indígenas da etnia Galibi Kalinã falam kalinã e português, e os Parlikur falam parikwaki e português.

\section{Políticas linguísticas in vitro e in vivo nas comunidades dos Karipuna do Amapá}

Para apresentação e discussão das políticas linguísticas in vitro e in vivo aplicadas nas/pelas comunidades do povo Karipuna do Amapá, é necessário, de antemão, entender a situação sociolinguística deste grupo, já evidenciada por Sanches (2019; 2020) que identifica o português como a língua mais usual na área indígena dos Karipuna quando comparado ao uso do kheuól, língua menos usual.

Essa forte presença do português pode ser explicada com base em fatores históricos e sociopolíticos da região do Oiapoque, como as políticas indigenistas executadas pelo Serviço de Proteção aos Índios - SPI (atual FUNAI), no século XX. Segundo Tassinari (2003), esse órgão tinha como propósito "abrasileirar" os povos indígenas da região do Oiapoque, chegando a proibir o uso do kheuól e impondo o uso do português. Tal política aplicada, por meio de mecanismos implícitos e explícitos como a escolarização, teve impacto negativo no que se refere à vitalidade do kheuól no cenário atual, reduzindo assim o número de indígenas falantes dessa variedade.

Com base na situação sociolinguística dos Karipuna, buscaremos neste artigo entender como as comunidades indígenas têm se organizado para restabelecer o uso do kheuól na área indígena pertencente ao grupo Karipuna do Amapá, e que estratégias político-linguísticas eles estão criando como forma de revitalizar ou manter o kheuól nas aldeias.

Os dados que serão analisados aqui procedem do corpus da Tese de Doutorado de Sanches (2020). A pesquisa foi realizada mediante autorização do Conselho de Caciques dos Povos indígenas de Oiapoque - CCPIO, ofício de no 074/2017, e da Fundação Nacional do

\footnotetext{
${ }^{7}$ Os dados referentes ao quantitativo populacional e ao número de etnias e aldeias da região do Oiapoque foram fornecidos pela Fundação Nacional do Índio - FUNAI/Macapá.

${ }^{8}$ O estudo de Sanches (2020) mostra que, na constituição do kheuól dos Karipuna, há aspectos fonológicos, lexicais e sintáticos do português falado na região, além da influência indígena em que não se sabe a origem dessas línguas. Há fontes históricas que apontam para um Karipuna antigo, outras para uma Língua Geral Amazônica.
} 
Índio - FUNAI, ofício de no 26/2018. Ressaltamos também que todas as entrevistas foram autorizadas pelos indígenas por meio de áudio MP3, tendo em vista a dificuldade de escrita encontrada por eles. $\mathrm{O}$ corpus conta com três tipos de questionários aplicados a um total de 36 indígenas bilíngues do povo indígena Karipuna do Amapá. Sanches (2020) investigou nove aldeias desta etnia, com uma amostra de quatro colaboradores por localidade.

Para alcançarmos o objetivo deste estudo, propusemo-nos a analisar seis questões do Questionário Sociolinguístico (Qsócio) ${ }^{9}$ da Tese supracitada. As questões selecionadas são pertinentes ao debate ora empreendido, dado que traz à luz aspectos relacionados ao uso e vitalidade do kheuól nas comunidades pesquisadas e à representação identitária dessa variedade linguística. Os dados permitem também correlacionar esses aspectos às expectativas de ações advindas do poder público para a manutenção da língua (políticas in vitro), bem como às iniciativas de autorregulação promovidas pelas comunidades (políticas in vivo). Abaixo seguem as questões que serão analisadas.

Quadro 1-Questões selecionadas

\begin{tabular}{|ll|}
\hline № & \multicolumn{1}{c|}{ QUESTÕES } \\
\hline 17 & Todas as pessoas daqui falam kheuól? Quem? \\
18 & Quando vem uma visita indígena, que línguas vocês usam? \\
19 & Que línguas são faladas na comunidade? \\
20 & Como o senhor avalia o kheuól em termos de língua falada no lugar? \\
21 & O que o senhor espera que o governo faça para preservar a língua da comunidade? \\
22 & E o que a comunidade tem feito para preservá-la? \\
\hline
\end{tabular}

Fonte: Elaboração dos autores.

A primeira questão analisada corresponde a de número 17 do questionário sociolinguístico. A partir dela, buscamos saber em quais domínios de uso os colaboradores entrevistados usam o kheuól nas aldeias. As respostas obtidas mostram que o uso dessa variedade é realizado com maior frequência na presença dos pais e avós, com destaque para a figura materna, e em seguida pelos demais familiares (irmãos, tios e primos), o que caracteriza um uso mais expressivo no âmbito familiar. O segundo domínio de uso mais expressivo é o espaço escolar, incentivado pelo professor indígena, e em menor escala, segundo os colaboradores, o kheuól também é usado na presença de vizinhos, líderes religiosos, amigos e outras pessoas, neste caso citam-se os cônjuges, esposas ou maridos, conforme podemos observar no Gráfico 1.

\footnotetext{
${ }^{9}$ O Questionário Sociolinguístico, utilizado para pesquisa de Sanches (2020), foi elaborado pelo Projeto Atlas Linguístico do Português falado em Área Indígenas - ALiPAl, coordenado pelo professor Abdelhak Razky, na Universidade Federal do Pará - UFPA. O questionário contém no total de 22 questões e foi aplicado em forma de entrevista, buscando fazer o levantamento do perfil sociolinguístico das comunidades indígenas Karipuna. Para tal, Sanches realizou pesquisa in loco entre os anos 2017-2018.
} 
Gráfico 1 - Porcentagem de pessoas com que se fala kheuól nas aldeias

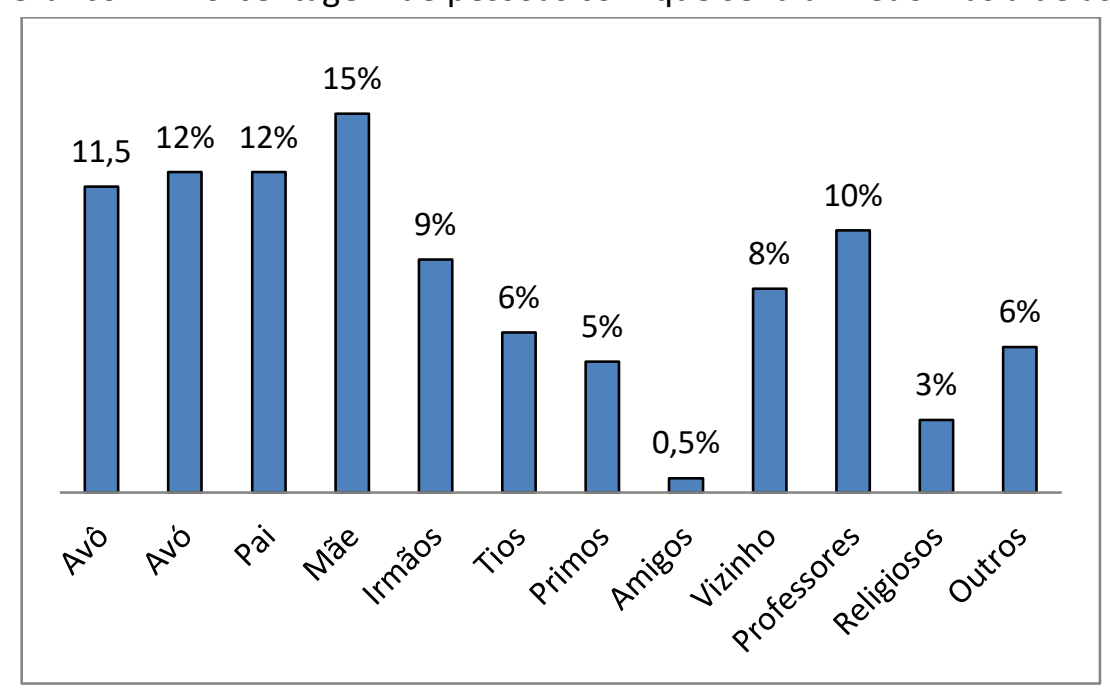

Fonte: Elaboração dos autores.

Conforme explicita Corbeil (2002), a família e a escola são dois dos mais importantes domínios sociais de uso a se considerar em um projeto de planificação linguística. O uso da língua na família e na escola são indicativos de que a manutenção da língua pode ser assegurada pelas gerações caso as famílias estejam conscientemente envolvidas e implicadas no processo. No entanto, quando analisamos as respostas apresentadas acima, por aldeia investigada, percebemos que o uso do kheuól é predominante apenas nas aldeias Espírito Santo e Açaizal, tendo em vista que nelas a maioria dos colaboradores informou que fala a língua com qualquer pessoa da comunidade. Nas demais aldeias o uso é restrito, comumente praticado na presença de pais ou avós.

Com a segunda questão, número 18 , buscamos saber qual língua era usada na comunidade na presença de uma visita indígena, em um domínio extrafamiliar, ou seja, com falantes de outros grupos indígenas. Com isso, identificamos que $82 \%$ (28) dos colaboradores da pesquisa informaram que usam o português e apenas $22 \%$ (8) disseram usar o kheuól. Na realização desta última variedade, observa-se, cf. o Gráfico 2, que o uso do kheuól é bastante variável entre as comunidades. Se na aldeia Espírito Santo destaca-se o fato de que todos os colaboradores indicam falar o kheuól em diferentes domínios sociais, já na aldeia Açaizal percebe-se a ocorrência equilibrada com o uso do português. Nas aldeias Curipi e Kariá, o uso do kheuól se mostra enfraquecido, e o português é predominante nas aldeias Manga, Santa Isabel, Ahumã, Ariramba e Kunanã, onde todos os colaboradores disseram usar apenas o português quando recebem uma visita indígena.

O uso predominante do português ou em situação de conflito diglóssico (cf. HAMEL, 1988) com o kheuól reflete as sérias investidas do estado brasileiro na homogeneização do português no Brasil, bem como no apagamento das línguas nativas indígenas. Essa situação resulta do contato assimétrico que provocou o deslocamento do kheuól pela língua hegemônica como em diversos outros casos relatados na literatura ${ }^{10}$, e traz consigo

\footnotetext{
${ }^{10}$ Ver Braggio (2002; 2003); Guimarães (2002) e Albuquerque (1999).
} 
múltiplas mudanças funcionais e no próprio ecossistema da língua quando da passagem de uma geração para outra.

Os dados do Gráfico 2 apontam para um forte desequilíbrio no uso do português e do kheuól nas comunidades Karipuna do Amapá, em que o português é predominante em 7 das 9 aldeias pesquisadas. Essa situação do uso do português de modo frequente nas interações intergrupais (de indígenas com outros grupos indígenas), também foi apontada no estudo de Albuquerque (1999), nas interações entre Apinayé-Apynayé.

Considerando a classificação de Fishman $(1991)^{11}$ sobre os níveis de ameaça ou extinção de uma língua, esse cenário pode indicar um dos níveis de fator de risco para a vitalidade do kheuól, uma vez que seu uso fica caracterizado, primordialmente, como de uso familiar e exibe uma falta de coesão social em relação ao uso da língua. Por outro lado, conforme veremos a seguir, a realidade constatada nos dados vai ao encontro das inquietações das comunidades quanto ao pouco uso da língua pelas famílias e aos esforços identificados por eles para mudar a situação atual.

\section{Gráfico 2 - Língua usada na presença de visitas indígenas}

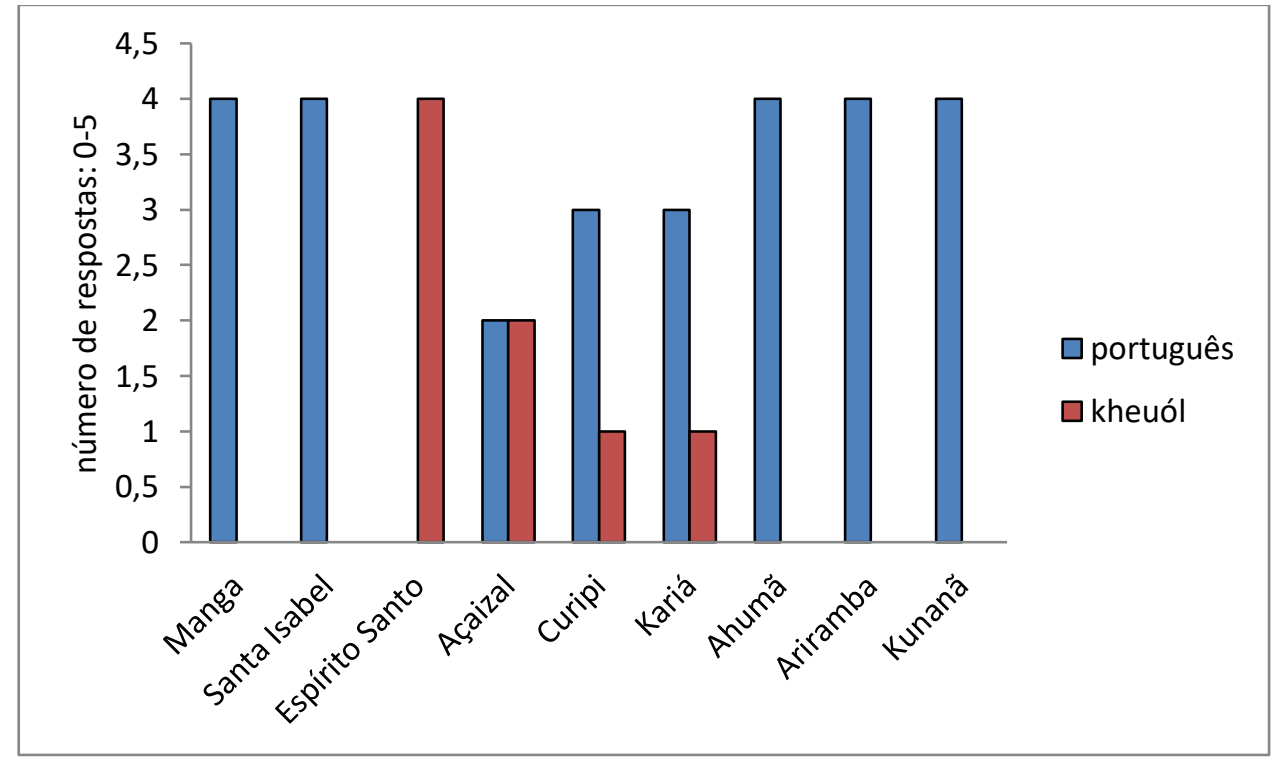

Fonte: Elaboração dos autores.

Através da terceira questão, número 19, buscamos identificar quais outras línguas são utilizadas nas comunidades, em decorrência das aldeias estarem situadas em área de fronteira entre Brasil e Guiana Francesa, considerando que a presença de duas línguas majoritárias (português e francês) poderia trazer ainda mais impacto no uso da variedade falada pelos indígenas. Por meio do questionário, a maioria dos colaboradores informou que em suas aldeias as pessoas usam o português e o kheuól e apenas um colaborador apontou

\footnotetext{
${ }^{11}$ Estágio 8: Somente alguns mais velhos usam a língua; Estágio 7: Somente adultos usam a língua; Estágio 6: Há algum uso intergerações da língua; Estágio 5: A língua está viva e sendo usada na comunidade; Estágio 4: A língua é utilizada no ensino básico da 1a. Fase; Estágio 3: A língua é utilizada nos locais de negócios; Estágio 2: A língua é usada pelo governo local e na mídia; Estágio 1: A língua é usada pela esfera governamental mais alta e para educação. (FISHMAN, 1991, p. 109 apud BRAGGIO, 2003, p. 117).
} 
que na aldeia Manga também se fala francês, além do português e kheuól. O Gráfico 3 mostra o uso destas línguas em cada comunidade.

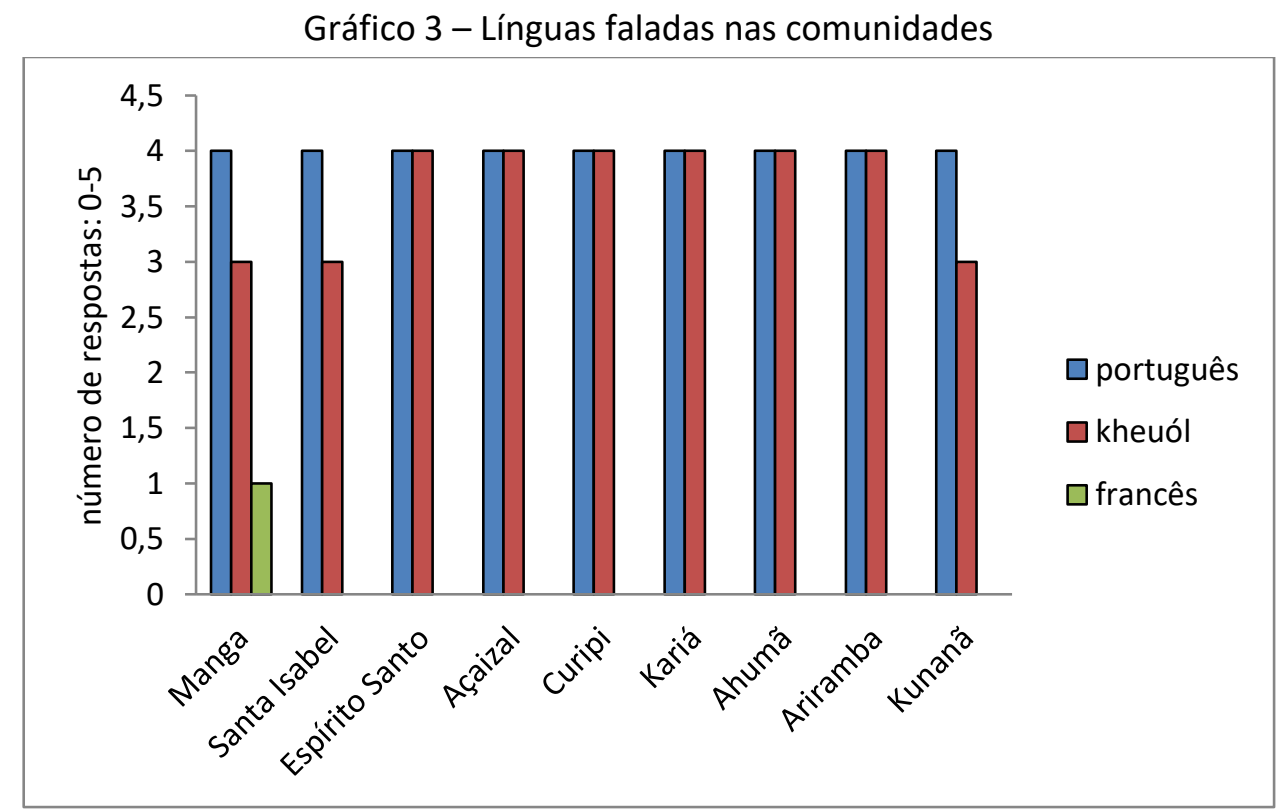

Fonte: Elaboração dos autores.

Com a quarta questão, número 20, buscamos saber como os colaboradores indígenas, em termos de representação identitária, avaliam o kheuól falado na comunidade. Assim, cerca de $80 \%$ (29) das respostas caracterizou o kheuól como uma língua bonita, 17\% (6) disseram que é uma língua legal e 3\% (1) avaliaram como uma língua feia e que não gostam de usá-la. Essa avaliação se mostra importante, pois é a partir dela que se pode avaliar uma possível implicatura do indígena em uma política de revitalização ou de manutenção da língua. O Gráfico 4 mostra a avaliação por localidade.

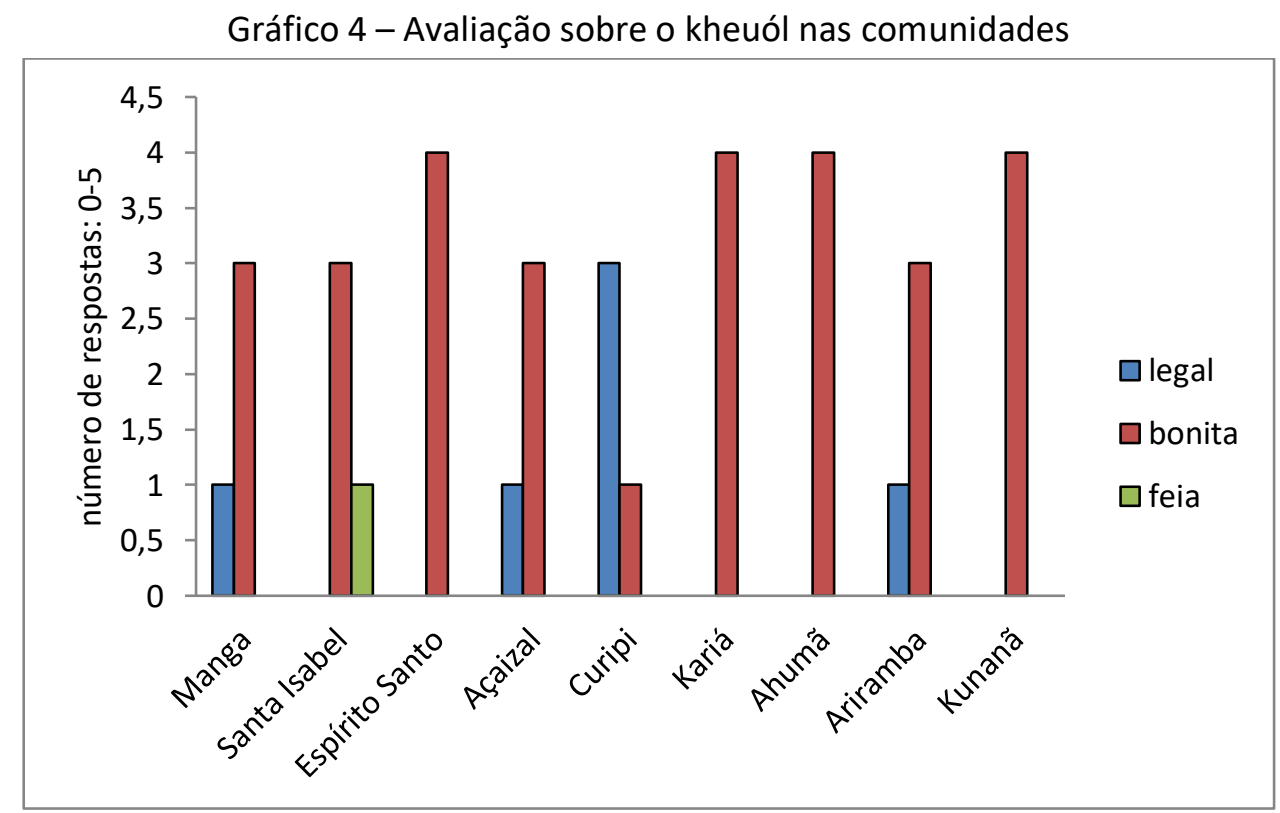

Fonte: Elaboração dos autores. 
Em relação às comunidades, o Gráfico 4 aponta que nas aldeias Espírito Santo, Kariá, Ahumã e Kunanã todos os colaboradores avaliaram a língua como bonita e somente na aldeia Santa Isabel houve uma avaliação negativa. Sobre as avaliações positivas, destaca-se que a maioria dos colaboradores justifica sua avaliação, associando o kheuól como traço cultural e identitário do povo Karipuna. Percebe-se que há também forte conscientização dos colaboradores em compreender o kheuól como autoafirmação étnica, como mostram os trechos a seguir:

\footnotetext{
- Representa a gente como povo. Eu gosto de falar minha língua, se eu pudesse eu falava só ela em todos os cantos ( $C 1^{12}$ - aldeia Espírito Santo.

- É nossa língua tradicional. É do povo Karipuna. Eu acho bonito pra quem sabe falar e escrever (C3 - aldeia Açaizal).

- Porque eu como índia não sou inferior a ninguém, eu acho bonita e eu gosto, tenho orgulho de falar ela (C1 - aldeia Kariá).

- Nossa língua faz parte da gente. Ela é nossa identidade nosso povo. Ela representa a gente (C4 - aldeia Manga).

- Não podemos perder a língua, porque a gente tem que dançar o Turé ${ }^{13}$. É nossa cultura (C2 - aldeia Ariramba).
}

Com a quinta questão, número 21 , buscamos saber o que eles esperam do governo para preservar a língua da comunidade. Essa pergunta evocou certas expectativas das comunidades indígenas quanto às políticas in vitro, ou seja, aquelas que emanam do poder público para a preservação da variedade linguística usada por eles, neste caso, o kheuól. Uma maior presença da língua na escola surge como unidade de consenso em todas as aldeias. Termos como "fazer mais", "preservar", "investir", "valorizar" relativos à presença do kheuól na escola aparecem frequentemente acompanhados das ações que as tornariam mais efetivas, tais como: "formar professores indígenas bilíngues", "dar apoio aos professores", "fornecer material didático nas línguas", "construir material próprio".

Observamos, portanto, que as demandas das comunidades abrangem um contínuo que engloba tanto a planificação do status do kheuól quanto uma planificação do corpus, ou seja, a esperada valorização da língua na escola (status), implican do em uma presença mais efetiva. Isso pode reverberar para toda a comunidade, passa, no dizer dos próprios indígenas por uma política de investimento na escrita dessa mesma língua. Essa situação é corroborada por Haugen (1972), entendendo que planificar o status de uma língua implica em ações que consolidem a presença dessa língua em uma dada sociedade, e no sentido inverso, todo investimento no corpus implica um novo status para uma língua.

Conforme afirma Guimarães (2002, p. 49), optar pelo uso do kheuól na escola, neste caso, configura-se como uma "decisão estratégica e tem suas raízes no projeto social do grupo", assentada na ideia de que tal política de defesa da própria língua constitui uma

\footnotetext{
12 Para a não identificação dos colaboradores, usaremos a convenção $\mathrm{C}+\mathrm{N} N$, por exemplo, a letra $\mathrm{C}$ representa Colaborador e o número ao lado da letra, como $\mathrm{C} 1$, indica que é o primeiro dos quatro colaboradores entrevistados em cada aldeia.

${ }^{13}$ É uma festa tradicional dos povos indígenas do baixo Oiapoque, em que os indígenas aproveitam para agradecer os seres sobrenaturais e invisíveis pelas curas obtidas por meio das práticas xamânicas dos pajés.
} 
"estratégia de resistência sociocultural e mecanismo de construção da consciência da identidade étnica no espaço escolar".

Nessa mesma linha, no que concerne à gestão do kheuól, política e planificação linguística aparecem como ações contínuas nos depoimentos dos indígenas, uma vez que idealizar um uso mais frequente de uma língua implica em planejar as ações necessárias para que tal objetivo seja alcançado. Assim, construção de material didático próprio, formação de professores indígenas bilíngues e ensino bilíngue para as crianças apontam para o objetivo final que é a revitalização e manutenção do kheuól na comunidade, isto é, para uma planificação da aquisição, conforme delimitação estabelecida por Cooper (1989).

Embora, em tese, todas as ações demandadas pelas comunidades estejam previstas e juridicamente asseguradas pela constituição e pela LDB 9394/96, a existência do suporte legal não garante a execução dos direitos afiançados em tais documentos. Os mecanismos de uma política oculta, não declarada, que prega a inviabilidade econômica da política oficial rivaliza com as determinações legais. A formação de professores indígenas bilíngues, além de relativamente recente, não contempla grande parte das comunidades amazônicas, tampouco existe material didático em todas as línguas usadas nas diferentes etnias, ou investimento na normatização dessas línguas. Resta dizer nesse cenário, que as políticas in vitro apontam para a ineficiência ou inexistência de ações planificadoras nestas comunidades. Para além disso, a inobservância displicente do que dispõe a constituição nada mais é senão um dos muitos mecanismos ocultos de política linguística implícita conforme menciona Shohamy (2006).

De acordo com Rousseau (2005), as políticas que normalmente alçam sucesso, em geral, são aquelas sustentadas pelas comunidades linguísticas implicadas ou são por elas implementadas. Estas últimas são as chamadas iniciativas autorregulatórias, denominadas por Calvet (1996) de políticas in vivo. Visando aferir tanto o nível de valorização da variedade falada por indígenas nas comunidades quanto elencar ações de revitalização ou manutenção por elas iniciadas, a pergunta de número 22, última questão, indagou aos colaboradores indígenas o que a comunidade tem feito para preservar o kheuól.

Consoante ao que fora anteriormente discutido neste texto, qualquer projeto de planificação linguística, in vivo ou in vitro, fundamenta-se na visão que se tem da situação existente e do futuro linguístico que se almeja alcançar mediante as relações estabelecidas entre as comunidades linguísticas em presença. A noção do processo de perda linguística do kheuól nas comunidades indígenas fica evidenciada em depoimentos pontuais, conforme é possível observar nos excertos abaixo:

- Porque a própria língua a gente tá perdendo (C4 - aldeia Espírito Santo).

- A gente tá sentindo falta da língua (C1 - aldeia Kariá).

- A comunidade tem se preocupado com isso, mas a nossa própria língua tem ficado um pouco de lado (C3 - aldeia Kariá).

- Pra preservar a língua temos que incentivar mais os jovens, ensinar, se a gente não fizer isso a gente perde (C2 - aldeia Ahumã).

- A língua dos Karipuna não era o Patuá. Eles perderam (C2 - aldeia Manga). 
Depreende-se a partir dos depoimentos exibidos que a necessidade de preservar a língua se impõe como uma tarefa que envolve as práticas linguísticas da própria comunidade indígena. Nesse sentido, em cerca de $50 \%$ dos depoimentos, há indicativos de que as comunidades têm buscado "falar o kheuól nas reuniões e eventos" da etnia Karipuna e incentivado a comunidade a empregar mais a língua nas atividades cotidianas como forma de revitalizar e incentivar o uso da língua.

- A comunidade tem falado nas reuniões (C1 - aldeia Manga).

- A comunidade tem incentivado as famílias (C2 - aldeia Santa Isabel).

- Nas reuniões a gente só fala na língua Kheuól (C1 - aldeia Espírito Santo).

- Incentivando as famílias. Discutido em reuniões (C2 - aldeia Espírito Santo).

- Discutimos que não deixar a língua fracassada (C3 - aldeia Ahumã).

- Eles discutem nas reuniões (C4 - aldeia Kunanã).

De igual maneira, observa-se que as atitudes que negligenciam o uso das línguas pelas comunidades e famílias também são referenciadas nos depoimentos, indicando que a manutenção e sustentabilidade da língua não é tarefa de um indivíduo, mas de todas as famílias e da comunidade linguística como um todo. Os fragmentos abaixo indicam que essa prática é uma preocupação para os Karipuna.

- A comunidade não incentiva (C1 - aldeia Santa Isabel).

- Tá faltando incentivar as crianças a falar (C3 - aldeia Açaizal).

- A comunidade só faz o mínimo, não faz quase nada. A gente como liderança incentiva a comunidade a falar com seus filhos. Mas tá tão apegado ao português que quase não se interessa em falar a língua (C3 - aldeia Curupi).

- É pouco. Não falam muito. As famílias não tão conversando na língua (C2 - aldeia Kariá).

- Falta incentivo dos pais né!? Porque têm pais que a mãe fala bem a língua e não fala com as crianças ( $\mathrm{C} 1$ - aldeia Ariramba).

- Não tô vendo esforço nenhum (C4 - aldeia Ariramba).

Outra estratégia que se destaca nos depoimentos diz respeito ao "incentivo às famílias a ensinar o 'patuá14' às crianças e aos jovens", referenciada, por exemplo, nos depoimentos abaixo.

- A comunidade tem falado nas reuniões pras famílias ensinar os filhos a falar patuá (C1 - aldeia Manga);

- A comunidade incentiva. Ensina a criança a falar a língua. (C3 - aldeia Santa Isabel)

- As famílias incentivam as crianças. Mas não são todas (C1 - aldeia Açaizal).

- A Cacique fala nas reuniões pros pais falar mais na língua com os filhos. (C1 aldeia Curupi)

- Eu sempre falo pra eles nas reuniões pros pais falar mais na língua com os filhos. (C2 - aldeia Curupi)

- Nas reuniões eles falam pros pais ensinar as crianças a falar a língua. Principalmente os padres procura nos orientar nossa criança, pra não deixar de falar nossa língua, ensinar pra nossas línguas (C4 - aldeia Kariá)

- Pra preservar a língua temos que incentivar mais os jovens, ensinar, se a gente

\footnotetext{
${ }^{14}$ Patuá é denominação comum atribuída ao kheuól nas aldeias. Na cidade de Oiapoque, o uso desse termo tem forte carga discriminatória.
} 
não fizer isso a gente perde (C2 - aldeia Ahumã);

- Sempre a professora diz que é pra reservar mais, falar em casa com as crianças (C2 - aldeia Ariramba);

- Os pais incentivam os filhos a estudar (C1 - aldeia Kunanã).

Tais dados tanto informam sobre o processo de conscientização e da necessidade de preservação da língua pela própria comunidade, quanto indicam que as crianças são percebidas como sustentáculos da manutenção linguística, ainda que essa consciência seja proveniente de agentes, por vezes, externos à comunidade linguística como padres e professores ou de agentes internos em posição de liderança como é o caso de uma cacique (Cf. relato de C1 - aldeia Curipi). Em outro extremo desse contínuo, os mais velhos também são citados como fonte de resgate da língua, conforme se observa no depoimento abaixo:

A comunidade precisa de professores, pra não perder a identidade como indígena. Os idosos não contar como era, eles não vão saber (C4 - aldeia Manga).

Como indica Fishman (1991), a transmissão linguística entre gerações é um fator importante para o processo de manutenção de uma língua, e nesse sentido as comunidades Karipuna aparentam estar bastante conscientes do papel dos idosos na transmissão da língua para os mais jovens. Para além das estratégias já mencionadas, aparecem outras de caráter mais estrutural na formação das famílias, como evitar o casamento de índio com pessoa de fora da comunidade indígena, sugerida por um informante de uma das aldeias, indicando que a perda linguística vai muito além de fatores puramente linguísticos.

Por fim, o que se percebe, inclusive em correlação com outros trabalhos já realizados (BRAGGIO, 2002, 2003, 2015; GUIMARÃES, 2002; ALBUQUERQUE, 1999), é que as políticas ora adotadas representam uma tentativa de enfrentamento ao preconceito e estigmatização que sofrem esses povos e suas línguas, atitudes essas que estão por trás de práticas seculares de estereotipação, negação e abandono das línguas indígenas. Além disso, conforme defende Grosjean (1982), optar pelo ensino da língua nativa na comunidade fortalece a identidade do grupo e estabelece uma atitude positiva para com a língua.

\section{Considerações finais}

Lançar um olhar para as relações entre línguas, sociedades e suas respectivas políticas linguísticas, como propõe este trabalho, possibilita analisar em que medida as forças sociais atuam nas mudanças linguísticas e têm nas escolhas políticas o reflexo de suas aspirações.

O kheuól, como as demais línguas faladas por indígenas no Brasil, é uma sobrevivente. As políticas linguísticas oficiais, sustentadas pelo aparato do Estado, nunca estiveram a serviço da preservação do patrimônio linguístico nacional e seguramente, mesmo quando se propõem a fazê-lo não asseguram a consubstancialidade necessária para a efetividade das propostas desenhadas em gabinetes, e, portanto, distantes dos contextos sócio-históricos das comunidades a que se destinam. O Estatuto do índio e a própria LDB 
9394/96 são exemplos disso, indicadores de que vínculos frágeis entre política e planificação podem trazer resultados pouco eficazes (ROMAINE, 2002, p. 195).

Resta às comunidades indígenas, quando conscientes (ou chamadas à consciência por agentes externos) do papel da língua na preservação de suas identidades étnicas e culturais, esboçar projetos, mesmo que incipientes, de resgate e/ou manutenção de suas raízes linguísticas.

Ainda que aparentemente recentes, as iniciativas autorregulatórias da etnia Karipuna apontam para a construção de uma política linguística fundamentada na conscientização etnolinguística das comunidades indígenas que têm no kheuól uma das, senão a maior, referência de identidade linguístico-cultural daquele povo. As escolhas conscientes, que na definição de Calvet (2002) caracterizam as políticas linguísticas, estão no cerne das ações promovidas e reivindicadas em prol do kheuól nas aldeias Karipuna.

Assim, em consonância com os resultados já apresentados por Sanches (2019; 2020), os dados discutidos na seção anterior confirmam o português como variedade majoritária nas comunidades indígenas investigadas, sendo comumente empregada intra e entre comunidades. Não obstante, ressalta-se que: 1 ) os dados informam igualmente que os falantes ainda guardam uma representação positiva da língua; 2) que mantêm com ela vínculos identitários; e 3) que reconhecem o processo de perda linguística instaurado em função do uso contínuo do português nas comunidades. Essas referências constituem o sedimento basilar que impulsiona tanto as ações reivindicadas ao poder público (políticas in vitro) - ensino bilíngue, professores bilíngues indígenas, maior apoio para as escolas indígenas, material didático próprio - quanto às iniciativas implementadas pelas comunidades, inclusive como prática de autoafirmação etnolinguística (políticas in vivo) que envolvem falar sempre o kheuól nas reuniões comunitárias, incentivar o uso da língua nas famílias, ensinar crianças e jovens, recorrer aos mais velhos para ensinar aos mais jovens e até mesmo evitar casamento entre indígenas e não indígenas.

Em termos de gestão, o que fica evidente a partir dos dados é a busca por uma renovação dos usos e papéis sociais do kheuól nas comunidades indígenas Karipuna, e, por conseguinte de um novo valor social que se associe às funções desempenhadas por essa variedade. Nesse sentido, a escola ganha uma função político-linguística relevante como guardiã da oficialidade, da legitimidade, da forma e do status da língua no contexto sociolinguístico das aldeias.

Por fim, acreditamos que estudos desse gênero possibilitam oferecer um olhar macro para a diversidade linguística brasileira ao mesmo tempo em que reafirmam a singularidade de cada situação sociolinguística instaurada nas diferentes comunidades linguísticas. A adoção de políticas linguísticas, nesse cenário, demanda além de investimentos criteriosos no conhecimento dos ambientes linguísticos em que se inserem as línguas, práticas que respeitem o querer, a simbologia e as funções identitárias que estas ocupam no seio de cada comunidade. 


\section{Referências}

ALBUQUerQUE, F. E. Contato dos Apinayé de Riachinho e Bonito com o português: aspectos da situação sociolingüística. 132 f. Dissertação (Mestrado em Letras e Lingüística). Faculdade de Letras, Universidade Federal de Goiás, Goiânia, 1999.

BRAGGIO, S. O papel da pesquisa sociolingüística em projetos de educação, vitalização de língua e cultura: relatos sociolingüísticos iniciais dos Avá-Canoeiro de Minaçu. LIAMES, Campinas, v. 3, n. 1, p. 113-133, 2003. https://doi.org/10.20396/liames.v3i1.1416

BRAGGIO, S. Políticas e direitos linguísticos dos povos indígenas brasileiros. Signótica, v. 14, n.1, p. 129-146, 2002.

BRAGGIO, S. A variedade étnica Português Xerente Akwe: subsídios para a educação escolar indígena. PAPIA, São Paulo, v. 25, n. 1, p. 121-140, 2015.

BRASIL. Constituição (1988). Constituição da República Federativa do Brasil. Brasília, DF: Senado Federal: Centro Gráfico, 1988, 292 p.

BRASIL. Lei de Diretrizes e Bases da Educação Nacional (1996). Estabelece as diretrizes e bases da educação nacional. Brasília, DF: Centro Gráfico, Senado Federal, 2005, 64p.

BRASIL. Instituto Brasileiro de Geografia e Estatística - IBGE. Censo de 2010. Disponível em: http://www.ibge.gov.br/home/estatistica/populacao/censo2010/caracteristicas_gerais_indi genas/default_caracteristicas_gerais_indigenas.shtm. Acesso em: 22 mar. 2015.

BRASIL. Lei 6001, de 19 de dezembro de 1973. Dispõe sobre o Estatuto do Índio. Brasília, 975. Disponível em: http://www.planalto.gov.br/ccivil_03/Leis/L6001.htm. Acesso em 21 de janeiro de 2020.

BRASIL. Guia de pesquisa e documentação para o INDL. IPHAN: Brasília, 2014.

BRASIL. Ministério de Educação e do Desporto. Referencial curricular nacional para as escolas indígenas. Brasília, DF: MEC/SEF, 1998.

CALVET L.-J. Les politiques linguistiques. Paris: PUF, 1996.

CALVET, L.-J. As políticas linguísticas. Tradução Isabel Duarte, Jonas Tenfen, Marcos Bagno. São Paulo: Parábola Editorial, Ipol, 2007.

CALVET, L.-J. Cle marché aux langues. Les effets linguistiques de la mondialisation. Paris: Plon. 2002.

COOPER, R. L. Language Planning and Social Change. Cambridge: Cambridge University Press, 1989.

CORBEIL, J. C. Concurrence linguistique et promotion des langues. Congrès mondial sur les politiques linguistiques, $2002 . \quad$ Disponível em: http://www.linguapax.org/congres/taller/taller1/Corbeil.html Acesso em: 31 de janeiro de 2012.

COUDREAU, H. Chez nos indiens: quatre annés dans la Guyane Française (1887-1891). Paris, Librairie Hachette et Cie, 1893.

CREVAUX, J. Voyages dans L'Amérique du Sud. Paris: Librairie Hachette et Cie, 1883.

CRUZ, D. T. O ensino de língua estrangeira como meio de transformação social. In: MOTA, K.; 
SCHEYERL, D. (Orgs.). Espaços Linguísticos: resistências e expansões. Salvador: EDUFBA, 2006. p. 25-56.

D'AVITY, P. Description generale de L'Amerique troisesme partie du monde avec tovs ses empires, royavmes estats et republiques. Paris: Laurent Cottereav, 1643.

DAY, K. C. N. Políticas Linguísticas Educativas em conflito no Amapá: Impactos e contradições da LDB 9394/96 e da Lei 11.161/2005. 198f. Tese (Doutorado). Universidade Federal Fluminense. Rio de Janeiro, 2016.

FISHMAN, J. Maintaining Languages: what works? What doesn't? In: CANTONI, G. (Org.) Stabilizing Indigenous Language. Northern Arizona University Center for Excellence in Education Monograph $\quad$ Series, $1996 . \quad$ Disponível em: http://www.ncela.gwu.edu/pubs/stabilize/conclusion.htm. Acesso em: 22/11/ 2005.

FISHMAN, J. Reversing language shift: theoretical and empirical foundations of assistance to threatened languages. Bristol, PA: Multilingual Matters, 1991.

GROSJEAN, F. Life with Two Languages: An Introduction to Bilingualism. Cambrigde, MA: Harvard University Press, 1982.

GUIMARÃES, S. M. G. A aquisição da escrita e diversidade cultural a prática dos professores xerente. Brasília: FUNAI/DEDOC, 2002.

GUIMARÃES, S. M. G. Ciências Sociais no Projeto 3o Grau Indígena: focos principais Cadernos da Educação Escolar Indígena - 3o Grau indígena. Barra do Bugres: Unemat, v. 1, n. 1, p. 2533, 2002.

HAMEL, E. Language discourse and cultural models - three levels of language shift and maintenance. In: HERNANDEZ-CHAVES, E. The Journal of the Linguistic Association of the Southwest. Vol. 15, Guest Editor, University of the New Mexico, 1996. p. 63-88.

HAMEL, E. La política del lenguaje y el conflicto interétnico. Problemas de investigación sociolingüística. In: ORLANDI, E. P. (org.). Política linguística na América Latina. Campinas: Pontes, 1988. p. 41-74.

HAUGEN, E. The Ecology of language. Standford: Standford University press, 1972.

HURAULT, J.-M. Français et indiens em Guyane, 1604-1972. Paris: Union Générale d'Editions, 1972.

IPOL. Lista de línguas cooficiais em municípios brasileiros. Disponível em: http://ipol.org.br/lista-de-linguas-cooficiais-em-municipios-brasileiros/. Acesso em: 16 de abril de 2020.

KLOSS, H. Research Possibilities on Group Bilingualism. Quebec: International Center for Research on Bilingualism, 1969.

LAPORTE, P-E. Les mots clés du discours politique en aménagement linguistique au Québec et au Canada. In: TRUCHOT Claude et al., Le plurilinguisme européen, Théories et pratiques en politiques linguistiques. Paris: Éditions Champion, 1994, p. 97-107.

MOCQUET, J. Voyages em Afrique, Asie, Indies orientales e occidentales. Paris: Jean de Hierquevieu, 1617.

NIMUENDAJU, C. Os índios Palikur e seus vizinhos. Göteborg: Elanders boktr, 1926. 
ROBILLARD, D. Statut In: MOREAU, Marie-Louise (org.), Sociolinguistique, concepts de base. Paris: Margada, 1997. p. 269-270.

RODRIGUES, A. As Línguas Indígenas e a Constituinte. In: ORLANDI, E. P. (Org.). Política Linguística na América Latina. Campinas, Pontes, 1988. p. 105-109.

ROMAINE, S. The impact of language policy on endangered languages. International Journal on Multicultural Societies, v. 4, n. 2. UNESCO, 2002, p. 194-212.

ROUSSEAU, L.-J. Élaboration et mise en oeuvre des politiques linguistiques. Cahiers du Rifal, Bruxelles, n. 26, p. 58-71, 2005.

SANCHES, R. D. Bilinguismo entre os Karipuna do Amapá numa perspectiva geolinguística. In: OLIVEIRA, E. dos S.; VASCONCELOS, E. A.; SANCHES, R. D. (Orgs.). Estudos Linguísticos na Amazônia. Campinas, SP: Pontes Editores, 2019. p. 37-61.

SANCHES, R. D. Microatlas linguístico (português-kheuól) da área indígena dos Karipuna do Amapá. 247 f. Tese (Doutorado). Belém-PA: Universidade Federal do Pará (Programa de PósGraduação em Letras), 2020.

SAVEDRA, M.M; LAGARES, X. Política e planificação linguística: Conceitos, terminologias e intervenções no Brasil. Revista Gragoatá, Niterói: EdUFF, n. 32, p. 11-27, 2012.

SHOHAMY, E. Language policy: hidden agendas and new approaches. London: Routledge, 2006. https://doi.org/10.4324/9780203387962

SPOLKY, B. Language Policy. Cambridge: Cambridge University Press, 2004.

TASSINARI, A. M. I. No Bom da Festa: o processo de construção cultural das famílias Karipuna do Amapá. São Paulo: EDUSP, 2003.

Recebido em: 18/04/2020.

Aceito em: 25/06/2020. 